\title{
PENGARUH KESADARAN DAN PELAYANAN PERPAJAKAN TERHADAP KEPATUHAN PENGUSAHA KENA PAJAK DI MOJOKERTO
}

\author{
Oleh : \\ Nurrohman Harimulyono \\ (Dosen Jurusan Akuntansi STIE Al-Anwar Mojokerto) \\ Wida Primaningsih \\ (Alumni Jurusan Akuntansi STIE Al-Anwar Mojokerto)
}

\begin{abstract}
Abstrak
Langkah pemerintah untuk meningkatkan penerimaan dari sektor perpajakan dimulai dengan melakukan reformasi perpajakan secara menyeluruh pada tahun 1983, dan sejak saat itulah, Indonesia menganut sistem self assesment. Penerapan self assesment system akan efektif apabila kondisi kepatuhan sukarela (voluntary compliance) pada masyarakat telah terbentuk (Darmayanti, 2004). Kenyataan yang ada di Indonesia menunjukkan tingkat kepatuhan masih rendah, hal ini bisa dilihat dari belum optimalnya penerimaan pajak yang tercermin dari tax gap dan tax ratio. Tujuan yang ingin dicapai dalam penelitian ini adalah untuk mengetahui faktor faktor yang mempengaruhi kepatuhan pemilik usaha kecil menengah khususnya yang telah menjadi Pengusaha Kena Pajak (PKP) di Mojokerto, serta untuk mengetahui faktor apa yang paling dominan berpengaruh terhadap kepatuhan Pengusaha Kena Pajak dalam memenuhi kewajiban perpajakannya. Oleh karena itu variabel yang digunakan peneliti diantaranya kesadaran dan pelayanan perpajakan (sebagai variabel bebas) dan kepatuhan Pengusaha Kena Pajak (sebagai variabel terikat). Menurut hasil penelitian yang dilakukan oleh penulis maka diperoleh hasil bahwa semua faktor di atas mempunyai pengaruh positif dan signifikan terhadap kepatuhan Pengusaha Kena Pajak. Tetapi karena nilai signifikasi faktor kesadaran lebih besar dari nilai signifikasi faktor pelayanan perpajakan yaitu 0,004 $>0,042$, maka dapat disimpulkan faktor yang paling dominan mempengaruhi wajib pajak khususnya Pengusaha kena Pajak dalam memenuhi kewajiban perpajakannya adalah faktor kesadaran wajib pajak itu sendiri.
\end{abstract}

Kata kunci : kesadaran, pelayanan perpajakan, kepatuhan Pengusaha Kena Pajak

\section{Latar Belakang}

Peran pajak dalam Anggaran Pendapatan dan Belanja Negara (APBN) Indonesia terus meningkat terhadap seluruh pendapatan negara. Dalam APBN tahun anggaran 2002, target penerimaan yang berasal dari pajak untuk tahun anggaran 2002 sampai dengan 2005 terus meningkat. Peningkatan penerimaan APBN yang berasal dari pajak direncanakan akan berlangsung terus sampai APBN menjadi APBN mandiri pada tahun 2007.

Langkah pemerintah untuk meningkatkan penerimaan dari sektor perpajakan dimulai dengan melakukan reformasi perpajakan secara menyeluruh pada tahun 1983 , dan sejak saat itulah, Indonesia menganut sistem self assesment. Penerapan self assesment system akan efektif apabila kondisi kepatuhan sukarela (voluntary compliance) pada masyarakat telah terbentuk (Darmayanti, 2004). Kenyataan yang ada di Indonesia 
menunjukkan tingkat kepatuhan masih rendah, hal ini bisa dilihat dari belum optimalnya penerimaan pajak yang tercermin dari tax gap dan tax ratio.

Data yang akurat mengenai berapa jumlah tax gap Indonesia belum tersedia. Namun dalam pidato pengukuhannya sebagai guru besar Fakultas Ekonomi Universitas Indonesia, Gunadi mengutip hasil laporan Badan Pemeriksa Keuangan dan Pembangunan (BPKP) tentang audit kinerja Direktorat Jenderal Pajak, bahwa Indonesia mengalami tax gap yang cukup signifikan. (http: \www indodigest.com, 15 Maret 2006). Dari sisi lain, tax ratio Indonesia paling rendah di kawasan ASEAN yaitu hanya rata-rata sebesar 12,2 - 13,5 \% untuk tahun 2001 - 2006 (Berita Pajak, 1 September 2005). Sementara itu, tax ratio negara-negara ASEAN sebesar: Malaysia $(20,17 \%)$, Singapura $(21,4 \%)$, Brunai $(18,8 \%)$, dan Thailand (17,28\%). Angka tax gap yang signifikan dan tax ratio yang masih rendah ini menunjukkan usaha memungut pajak (tax effort) Indonesia rendah (Gunadi, 2004).

Untuk mencapai target pajak, perlu ditumbuhkan terus menerus kesadaran dan kepatuhan masyarakat wajib pajak untuk memenuhi kewajiban pajak sesuai dengan ketentuan yang berlaku. Mengingat kesadaran dan kepatuhan wajib pajak merupakan faktor penting bagi peningkatan penerimaan pajak, maka perlu secara intensif dikaji tentang faktor-faktor yang mempengaruhi kepatuhan wajib pajak, khususnya Pengusaha Kena Pajak.

Penelitian mengenai kepatuhan pajak sudah sering dilakukan. Beberapa peneliti menggunakan kerangka model Theory of Planned Behavior (TPB) untuk menjelaskan perilaku kepatuhan pajak Wajib Pajak Orang Pribadi (Blanthorne 2000; Bobek 2003). Model TPB yang digunakan dalam penelitian memberikan penjelasan yang signifikan, bahwa perilaku tidak patuh (noncompliance) wajib pajak sangat dipengaruhi oleh variabel sikap, norma subyektif, dan kontrol keperilakuan yang dipersepsikan. Bradley (1994) dan Siahaan (2005) melakukan penelitian kepatuhan wajib pajak badan dengan responden tax professional. Penelitian keduanya bukan merupakan penelitian perilaku. Tax professional adalah orang profesional di perusahaan yang ahli di bidang perpajakan. Oleh karena itu, untuk menjelaskan perilaku WP badan yang dalam hal ini diwakili oleh tax professional perlu menggunakan teori perilaku individu dan perilaku organisasi.

\section{Rumusan Masalah}

Berdasarkan variabel penelitian ini,perlu dituangkan dalam suatu rumusan masalah yang jelas guna memberikan arahan terhadap pembahasan selanjutnya. Adapun rumusan masalah dari penelitian ini adalah sebagai berikut :

1. Bagaimana pengaruh kesadaran dan pelayanan perpajakan secara simultan terhadap kepatuhan Pengusaha Kena Pajak (PKP) di Mojokerto

2. Bagaimana pengaruh kesadaran dan pelayanan perpajakan secara parsial terhadap kepatuhan Pengusaha Kena Pajak (PKP) di Mojokerto

3. Dari kedua variabel tersebut, variabel manakah yang paling besar pengaruhnya terhadap kepatuhan Pengusaha Kena Pajak (PKP) di Mojokerto

\section{Kerangka Pemikiran}

Faktor kesadaran Wajib Pajak sangat penting dalam melaksanakan Self Assesment System. Kesadaran adalah keadaan tahu, mengerti dan ingat kepada hal yang benar. Maka kesadaran terhadap Self Assesment System adalah tahu dan sepakat dan setuju bahwa Wajib Pajak diberikan kepercayaan yang sebesar besarnya untuk menghitung, memperhitungkan sendiri, menyetorkan, dan melaporkan pajak yang terutang kepada negara. Gunadi (2002) menyatakan bahwa 
keberhasilan Self Assesment System sangat dipengaruhi oleh kesadaran Wajib Pajak dalam menjalankan Self Assesment System.

Menurut IBFD (1996:266) Self Assessment System is system under which the tax payer is required to calculate the basis of this assessment (e.g. taxable income) to submit a calculation of the tax due and, usually, to accompany his calculation with payment of amount he regards as due. Ditekankan bahwa dalam menganut asas Self Assessment System diperlukan kesadaran dan kejujuran dari masyarakat Wajib Pajak untuk menghitung sendiri besaran pajaknya yang disertakan pada saat pembayaran atau pelunasan.

Menurut penelitian dari Roades (1979:78) menekankan pada aspek pentingnya kesadaran dan kepatuhan Wajib Pajak dalam melaporkan pendapatan bersih, karena dari hasil penelitiannya menyimpulkan Wajib Pajak seringkali tidak memberikan pelaporan mengenai pendapatan bersihnya. Variabel yang diajukan sebagai indikator Kesadaran Wajib Pajak adalah persepsi Wajib Pajak, pengetahuan perpajakan, karakteristik Wajib Pajak dan penyuluhan perpajakan.

1. Persepsi Wajib Pajak

Menurut Suripto (1996:10) Pada hakekatnya persepsi meliputi proses yang dilakukan seseorang dalam memahami informasi dan proses pemahaman ini melalui penglihatan, pendengaran dan perasaan. Dengan demikian persepsi merupakan proses aktivitas seseorang dalam memberikan kesan, penilaian, pendapat, memahami, mengorganisir, menafsirkan yang memungkinkan situasi, peristiwa yang dapat memberikan kesan perilaku yang positif atau negatif (Stephen, 1996 : 132; Hucynsky dan Buchanan, 1991:37). Dengan menyadari tentang apa yang diterima melalui indranya, berarti seseorang akan mengintepretasikan dan menilai suatu objek yang akan tercermin dar respon yang timbul, yang dapat berupa tanggapan atau perilaku.

Menurut Miftah (1996:130-137) faktor - faktor pembentuk persepsi ada dua yaitu faktor dari dalam diri dan faktor dari lingkungan. Faktor dari dalam diri terdiri dari proses belajar, motivasi dan kepribadian. (1) Proses belajar, merupakan proses perolehan pengetahuan melalui pengalaman (2) motivasi, merupakan fungsi dari berbagai macam variabel yang saling mempegaruhi dan merupakan proses psikologis yang menunjukkan usaha usaha tingkat tinggi untuk menjangkau tercapainya suatu tujuan (indrawijaya, 1989:676). Konsep motivasi dipergunakan untuk menunjukkan arah perilaku serta menjelaskan perbedaan dalam intensitas perilaku. (3) Kepribadian seseorang merupakan pola total cara berpikir, perasaan dan perilaku yang memberikan keabsahan mengenai perbedaan individu dalam kaitannya dengan lingkungannya. Dengan demikian kepribadian berkaitan dengan proses belajar dan motivasi.

Menurut penelitian mengenai persepsi Wajib Pajak terhadap kinerja penerimaan pajak dilakukan oleh Maria Karanta, et.al (2002:219) di Swedia. Mengkaji persepsi masyarakat terhadap kinerja Badan Perpajakan Nasional Swedia. Persepsi masyarakat Swedia dilihat dari : kesederhanaan prosedur yang bermanfaat bagi Wajib Pajak, kebutuhan Wajib Pajak, perlakuan yang adil, keahlian aparat pajak dalam mendeteksi kesalahan, serta dalam mengoreksi laporan pajak.

2. Pengetahuan Perpajakan

Menurut Fery Dwi Prasetyo (2006:24-25) Pengetahuan Wajib Pajak tentang pajak adalah proses pengubahan sikap dan tata laku seorang Wajib Pajak atau kelompok Wajib Pajak dalam usaha mendewasakan manusia melalui upaya pengajaran dan latihan. 
Pemahaman Wajib Pajak terhadap peraturan perpajakan adalah cara Wajib Pajak dalam memahami peraturan perpajakan yang telah ada. Banyak pelanggaran sistem Self Assessment yang terjadi karena Wajib Pajak tidak memiliki pemahaman perpajakan yang memadai. Ketidakpahaman terhadap sistem tersebut menyebabkan Wajib Pajak menggunakan jasa pihak ketiga dalam pengisian SPT tahunan. Menurut Ainie (2002), banyak pelanggaran sistem Self Assessment yang terjadi karena Wajib Pajak tidak memiliki pemahaman perpajakan yang memadai.

Fallan (1999:173-184) mengkaji pada aspek pentingnya pengetahuan perpajakan dalam mempengaruhi sikap Wajib Pajak dengan membedakan lakilaki dan perempuan. Peningkatan pengetahuan perpajakan memiliki signifikasi terhadap perubahan sikap antara laki-laki dan perempuan terhadap sistem perpajakan yang adil. Oleh karenanya sikap Wajib Pajak terhadap Badan Perpajakan akan dipengaruhi oleh pengetahuan Wajb Pajak mengenai perpajakan (Vogel, 1974; Soicer abd Loundstedt, 1976; Song and Yarbough, 1978; Laurin, 1986; Kinsey and Grasmick, 1993 dalam Fallan, 1999).

3. Karakteristik Wajib Pajak

Berkaitan dengan budaya membayar pajak penelitian yang dilakukan oleh Nerre (2001:17), menemukan bahwa dalam hal membudayakan pajak maka sebaiknya ada kerjasama (interaksi) baik formal maupun non formal antara instansi pajak dengan Wajib Pajak dengan membuat sistem perpajakan dan kebijakan perpajakan yang baik dan pelaksanaannya yang secara histories harus dipertimbangkan budaya suatu negara. Kotter dan Heskett (1997:85), juga menjelaskan bahwa secara umum budaya memiliki pengaruh yang besar terhadap kinerja penerimaan pajak.

4. Penyuluhan Perpajakan

Penyuluhan perpajakan sebagai suatu sistem penyampaian informasi dan bimbingan perpajakan merupakan ujung tombak dalam pelaksanaan sistem Self Assessment agar masyarakat tergugah dan sadar untuk melaksanakan kewajiban perpajakannya. Proses penyuluhan dan sosialisasi pajak dalam jangka waktu panjang diharapkan dapat membuat masyarakat Wajib Pajak sadar membayar pajak. Melalui proses sosialisasi yang berkesinambungan diharapkan dapat membentuk sebuah masyarakat sadar membayar pajak, memiliki kepatuhan (compliance) yang memadai dan komitmen moral terhadap kewajiban perpajakannya.

Pelayanan merupakan salah satu unsur yang sangat penting dalam menciptakan kepuasan pelanggan. Salah satu cara untuk menempatkan hasil pelayanan yang lebih unggul daripada pesaing adalah dengan memberikan pelayanan yang baik, efisien dan cepat. Seorang Wajib Pajak yang pada dasarnya juga berperan sebagai seorang pelanggan berhak mendapatkan pelayanan yang baik ketika melakukan tarnsaksi dengan pihak Dirjen Pajak sebagai pihak penyedia layanan jasa. Dirjen Pajak adalah penyedia jasa yang bersifat monopoli karena tidak adanya pesaing yang bergerak pada bidang sejenis. Meskipun begitu ketidakpuasan seorang pelanggan dalam hal ini Wajib Pajak terhadap pelayanan yang diberikan akan berakibat pada citra Dirjen Pajak di mata konsumen tersebut. Adapun variabel yang diajukan sebagai indikator pelayanan perpajakan adalah kualitas SDM, ketentuan perpajakan dan Sistem Informasi Perpajakan, yaitu : 
1. Kualitas Sumber Daya Manusia (SDM)

Adapun faktor - faktor yang mempengaruhi kualitas pelayanan menurut Zeithaml Valerie terdiri dari lima faktor, antara lain :

a. Bukti langsung (tangible) yaitu penampilan kualitas dan alat - alat yang digunakan secara fisik, penampilan karyawan dan peralatan komunikasi

b. Keandalan (realibility) yaitu kemampuan memberikan pelayanan yang dijanjikan dengan segera, akurat dan memuaskan.

c. Daya tanggap (responsiveness) yaitu keinginan para staf dan karyawan untuk membantu para pelanggan, memberikan pelayanan dengan tanggap, dan mampu mengatasi keluhan para pelanggan dengan cepat.

d. Jaminan (assurance) yaitu tingkat pengetahuan dan tingkat kesopansantunan yang dimiliki karyawan, di samping kemampuan mereka untuk memberikan kepercayaan kepada pelanggan, dimana dimensi assurance merupakan penggabungan dari dimensi : Kemampuan (Competence), Kesopanan (Courtesy), Kepercayaan (Credibility), dan Empati (Empathy).

Kepatuhan Perpajakan dapat didefinisikan sebagai suatu keadaan dimana Wajib Pajak memenuhi kewajiban perpajakan dan melaksanakan hak perpajakannya. Kepatuhan ada dua macam yaitu kepatuhan formal dan kepatuhan material. Kepatuhan formal adalah suatu keadaan dimana Wajib Pajak memenuhi kewajiban perpajakan secara formal sesuai dengan ketentuan dalam Undang Undang Perpajakan. Misalnya ketentuan tentang batas waktu penyampaian SPT Tahunan. Sedangkan Kepatuhan Material adalah suatu keadaan dimana Wajib Pajak secara subtantif / hakekat memenuhi semua ketentuan material perpajakan. Kepatuhan material meliputi kepatuhan formal. Jadi Wajib Pajak yang memenuhi kepatuhan material dalam mengisi SPT Tahunan, adalah Wajib Pajak yang mengisi dengan jujur, baik dan benar SPT tersebut sesuai dengan ketentuan dalam Undang Undang Perpajakan dan menyampaikan ke kantor Pelayanan Pajak sebelum batas waktu.

Wajib Pajak patuh menurut Keputusan Dirjen Pajak Nomor KEP550/PJ/2000 adalah Wajib Pajak yang telah ditetapkan oleh direktur Jendral Pajak sebagai Wajib Pajak yang memenuhi kriteria tertentu sebagaimana dimaksud dalam Keputusan Mentri Keuangan Nomor 544/KMK.04/2000 tentang kriteria Wajib Pajak yang dapat diberikan pengembalian pendahuluan kelebihan pembayaran pajak. Adapun kriteria tersebut adalah sebagai berikut :

1. Tepat Waktu dalam penyampaian Surat Pemberitahuan untuk semua jenis pajak dalam 2 (dua) tahun terakhir

2. Tidak mempunyai tunggakan pajak untuk semua jenis pajak kecuali telah memperoleh izin untuk mengangsur atau menunda pembayaran pajak

3. Tidak pernah dijatuhi hukuman karena melakukan tindak pidana di bidang perpajakan dalam jangka waktu 10 (sepuluh) tahun terakhir.

Dari sisi Wajib Pajak terdapat dua faktor utama yang mendukung keberhasilan tingkat kepatuhan Wajib Pajak melaksanakan Sistem Self Assessment adalah faktor kesadaran dan faktor pengetahuan / pemahaman (Pamungkas, 2003). Sedangkan dari sisi Direktorat Jendral Pajak terdapat tiga faktor yang mendukung tingkat kepatuhan Wajib Pajak dalam melaksanakan sistem Self Assessment yaitu penyuluhan (sosialisasi), pelayanan perpajakan dan pengawasan perpajakan (Hutagaol,2005) 
Konsep dasar untuk menjelaskan pengaruh kesadaran Wajib Pajak dan pelayanan perpajakan terhadap kepatuhan Pengusaha Kena Pajak dapat digambarkan sebagai berikut:

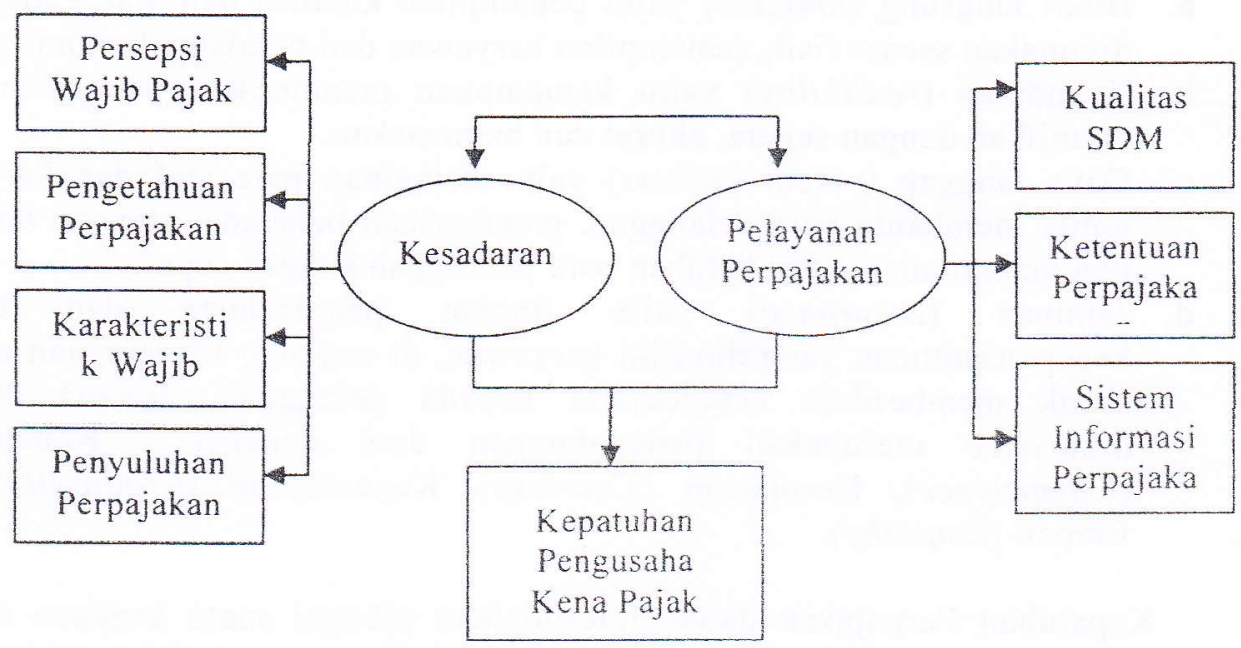

Gambar 2.1 : Hubungan Antar Variabel Kesadaran, Pelayanan Perpajakan Dan Pengaruhnya Terhadap Kepatuhan Pengusaha Kena Pajak (PKP)

Berdasarkan rumusan masalah yang telah dijelaskan sebelumnya maka peneliti dapat mengambil hipotesis yaitu :

1. Ada pengaruh positif signifikan antara kesadaran dan pelayanan perpajakan secara parsial terhadap kepatuhan Pengusaha Kena Pajak (PKP) di Mojokerto

2. Ada pengaruh positif signifikan antara kesadaran dan pelayanan perpajakan secara simultan terhadap kepatuhan Pengusaha Kena Pajak (PKP) di Mojokerto

\section{Metode Penelitian}

Jenis data yang dipergunakan dalam penelitian ini adalah data primer yang berupa kesadaran wajib pajak, pelayanan perpajakan dan kepatuhan wajib pajak dari pengusaha kena pajak (PKP) yang tergolong pengusaha kecil dan menengah (UKM) dan telah berbadan hukum. Penelitian ini didukung oleh data seluruh wajib pajak berbadan hukum dan telah terdaftar sebagai pengusaha kena pajak dan terdaftar pada Badan Pusat Statistik Mojokerto tahun 2007. Tehnik pengambilan sampel dalam penelitian ini dilakukan dengan metode Random sampling, kuesioner diberikan secara langsung kepada pengusaha kena pajak dan kemudian ditarik kembali setelah diisi oleh responden. Penyebaran kuesioner dan pengumpulan data penelitian dimulai pada tanggal $01 \mathrm{Mej} 2009$ sampai dengan 14 Juni 2009, dengan mendatangi secara langsung. 
Tabel Operasional Variabel

\begin{tabular}{|c|c|c|}
\hline Variabel & Indikator & $\begin{array}{c}\text { Pengukuran } \\
\text { Variabel }\end{array}$ \\
\hline $\begin{array}{l}\text { Kesadaran Wajib Pajak }\left(\mathbf{X}^{1}\right) \\
\text { Kesadaran Wajib Pajak, adalah } \\
\text { keadaan tahu, mengerti dan ingat } \\
\text { kepada hal yang benar. Maka } \\
\text { kesadaran terhadap Self Assesment } \\
\text { System adalah tahu dan sepakat } \\
\text { dan setuju bahwa wajib pajak } \\
\text { diberikan kepercayaan yang } \\
\text { sebesar - besarnya untuk } \\
\text { menghitung, memper-hitungkan } \\
\text { sendiri, menyetorkan, dan } \\
\text { melaporkan pajak yang terutang } \\
\text { kepada Negara. }\end{array}$ & $\begin{array}{l}\text { a. Persepsi Wajib Pajak } \\
\text { b. Pengetahuan } \\
\text { perpajakan } \\
\text { c. Karakteristik Wajib } \\
\text { Pajak } \\
\text { d. Penyuluhan } \\
\text { Perpajakan }\end{array}$ & Skala Likert \\
\hline $\begin{array}{l}\text { Pelayanan Perpajakan }\left(X^{2}\right) \\
\text { Pelayanan Perpajakan, merupakan } \\
\text { salah satu unsur yang sangat } \\
\text { penting dalam menciptakan } \\
\text { kepuasan pelanggan. Salah satu } \\
\text { cara untuk menempatkan ha sil } \\
\text { pelayanan yang lebih unggul } \\
\text { daripada pesaing adalah dengan } \\
\text { memberikan pelayanan yang baik, } \\
\text { efisien dan cepat. }\end{array}$ & $\begin{array}{l}\text { a. Kualitas SDM } \\
\text { b. Ketentuan } \\
\text { Perpajakan } \\
\text { c. Sistem Informasi } \\
\text { Perpajakan }\end{array}$ & Skala Likent \\
\hline $\begin{array}{l}\text { Kepatuhan Wajib Pajak (Y) } \\
\text { Wajib Pajak dikatakan patuh } \\
\text { apabila wajib pajak tersebut dapat } \\
\text { memenuhi dan melaksanakan } \\
\text { kewajiban perpajakan. Kewajiban } \\
\text { perpajakan harus dilaksanakan } \\
\text { karena kewajiban merupakan } \\
\text { suatu tanggung jawab yang harus } \\
\text { dipenuhi oleh wajib pajak. }\end{array}$ & $\begin{array}{l}\text { a. Ketepatan waktu } \\
\text { dalam penyampaian } \\
\text { SPT } \\
\text { b. Tidak memiliki } \\
\text { tunggakan pajak } \\
\text { c. Tidak pernah dijatuhi } \\
\text { hukuman karena } \\
\text { tindak pidana di } \\
\text { bidang Perpajakan }\end{array}$ & Skala Likert \\
\hline
\end{tabular}

\section{Tehnik Analisis Data}

\section{Statistik Deskriptif}

Analisis statistik deskriptif dimaksudkan untuk melihat gambaran umum mengenai demografi responden dan variable-variabel penelitian. Analisis ini disajikan dalam bentuk minimum, maximum, mean, serta standar deviasi.

\section{Uji Kualitas Data}

Suatu instrumen dikatakan valid bila mampu mengukur variabelnya. Dalam penelitian ini pengujian validitas data dilakukan dengan analisa faktor. Tujuannya untuk memastikan bahwa masing-masing pertanyaan telah mewakili variabelnya. Kemudian dilakukan pengujian reliabilitas data untuk mengetahui konsistensi hasil pengukuran variabel. Pengukuran yang reliabel menunjukkan instrumen tersebut dapat dipercaya sehingga akan menghasilkan data yang dapat dipercaya pula. 
Pengujian validitas dilakukan dengan menggunakan analisis korelasi product moment sedangkan uji reliabilitas menggunakan nilai cronbach alpha masingmasing variabel.

\section{Uji Hipotesis}

Untuk menguji hipotesis yang diturunkan, digunakan analisis regresi. Maka untuk memudahkan dan keakuratan hasil penelitian, maka data yang diperoleh dari penyebaran kuesioner dihitung dengan menggunakan program pengolah statistik SPSS versi 14.00 dan selanjutnya pembahasannya dikorelasikan dengan aspekaspek kepatuhan wajib pajak untuk menguji hipotesis dalam penelitian ini. Maka dibuatlah formulasi model regresi sederhana yang digunakan pada penelitian ini, yaitu sebagai berikut:

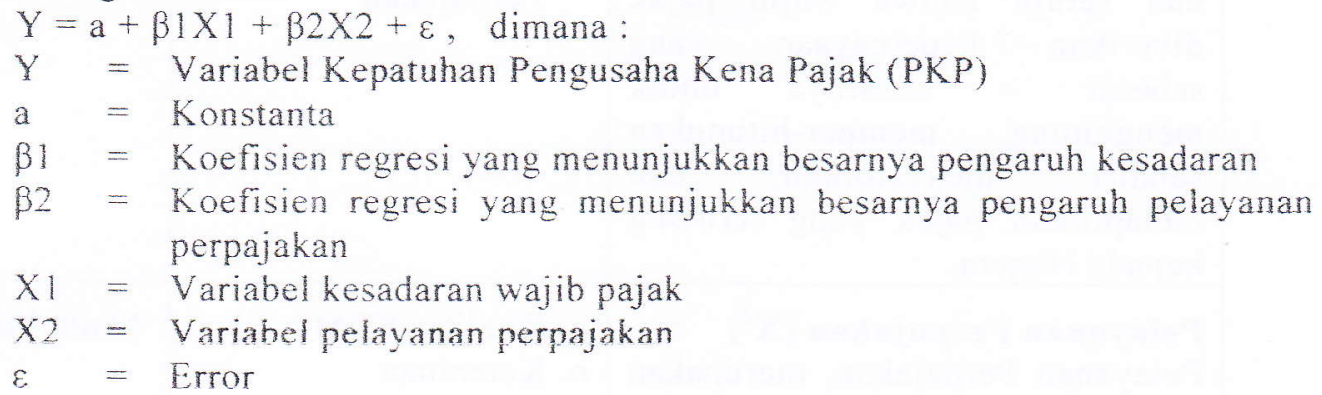

\section{Hasil Penelitian}

Data penelitian dikumpulkan dengan mengirimkan kuesioner kepada wajib pajak PKP. Penelitian ini didukung oleh data dari Badan Pusat Statistik Mojokerto. Jumlah Kuesioner yang dikirimkan sebanyak 30 eksemplar. Responden dalam penelitian ini rata - rata memiliki tingkat pendidikan yang tinggi atau setara dengan S1 dan sebagian besar pemilik usaha kecil menengah yaitu Pengusaha Kena Pajak (PKP) ini berjenis kelamin laki - laki dengan tingkat usia lebih dari 30 tahun. Semua responden telah mengisi dengan lengkap dan selanjutnya dapat dianalisis lebih lanjut dalam penelitian ini.

Tabel 4.1: Jenis Usaha Responden

\begin{tabular}{|c|l|c|}
\hline No & \multicolumn{1}{|c|}{ Jenis Usaha } & Jumlah \\
\hline 1 & Jasa Konstruksi & 5 \\
\hline 2 & Jasa Finance & 6 \\
\hline 3 & Asuransi & 1 \\
\hline 4 & Industri lainnya & 18 \\
\hline & Jumlah & 30 \\
\hline
\end{tabular}

Sumber: BPS 2007 data diolah

\section{Uji Kualitas Data}

Pengujian validitas dapat dilihat dari corrected item to total correlation coefficient. Dari hasil perhitungan uji validitas dengan menggunakan korelasi product moment menunjukkan bahwa semua pernyataan atau pertanyaan untuk angket / kuisioner memiliki korelasi $>0,306$, maka semua item pertanyaan tersebut dapat digunakan dan dapat dipercaya untuk mengumpulkan data yang diperlukan. 
Untuk mengukur reabilitas digunakan cronbach alpha coefficient yang mengukur konsistensi interval penggunaan instrumen - instrumen tersebut. Penguji melakukan uji reliabilitas dengan menghitung Cronbach alpha dari masing-masing iterm dalam suatu variable instrumen yang dipakai dalam variable tersebut dikatakan handal (reliable) apabilal memiliki Cronbach Alpha lebih dari 0,60 (Nunnaly, 1978). Reabilitas setiap pertanyaan dapat dilihat pada tabel 4.3

Tabel 4.2

\begin{tabular}{|l|c|c|}
\multicolumn{1}{c|}{ Hasil Uji Reabilitas Setiap Variabel } \\
\begin{tabular}{|l|c|c|}
\hline \multicolumn{1}{|c|}{ Variabel } & Cronbanch Alpha & Reabilitas \\
\hline Kesadaran & 0,809 & Realibel \\
\hline Pelayanan Perpajakan & 0,810 & Realibel \\
\hline Kepatuhan Wajib Pajak & 0,757 & Realibel \\
\hline
\end{tabular}
\end{tabular}

\section{Uji Asumsi Klasik Regresi}

Uji Multikoleniaritas

Multikolinearitas adalah terjadinya hubungan linear antara variabel bebas dalam persamaan regresi linear berganda. Apabila ternyata ada hubungan linear antar variabel bebas, maka persamaan regresi linear berganda tersebut multikolinier. Pendektesian adanya multikolinier digunakan nilai VIF $<10$, regresi linier berganda tersebut tidak terkena mil uji kolinearitas sebagai berikut: Tabel 4.3: Uji Multikolinearitas

\begin{tabular}{|l|c|c|c|}
\hline \multirow{2}{*}{ Tabel 4.3 : Uji Multikolinearitas } \\
\cline { 2 - 4 } & \multicolumn{2}{|c|}{ Collinearity Statistics } & \multirow{2}{*}{ Kesimpulan } \\
\cline { 2 - 4 } & Tolerance & Nilai VIF & \\
\hline Kesadaran & 0,991 & 1.009 & Tidak terjadi multikoleniaritas \\
\hline Pelayanan Perpajakan & 0,991 & 1.009 & Tidak terjadi multikoleniaritas \\
\hline
\end{tabular}

Uji Heterokedastisitas

Untuk mendeteksi ada tidaknya heterokedastisitas yaitu dengan melihat ada tidaknya pola tertentu pada grafik, di mana sumbu $X$ dan $Y$ yang telah diprediksi, dan sumbu $X$ adalah residual ( $Y$ prediksi - Y sesungguhnya) yang telah distudentized. Jika ada pola tertentu, seperti titik - titik (poin - poin) yang membentuk suatu pola tertentu yang teratur (bergelombang, melebar kemudian menyempit), maka telah terjadi heterokedastisitas. Jika tidak ada pola yang jelas, serta titik titik menyebar dan di bawah angka 0 pada sumbu $Y$, maka tidak terjadi Heterokedastisitas. 
Gambar 4.3 : Scatterplots Standarized Residual Value

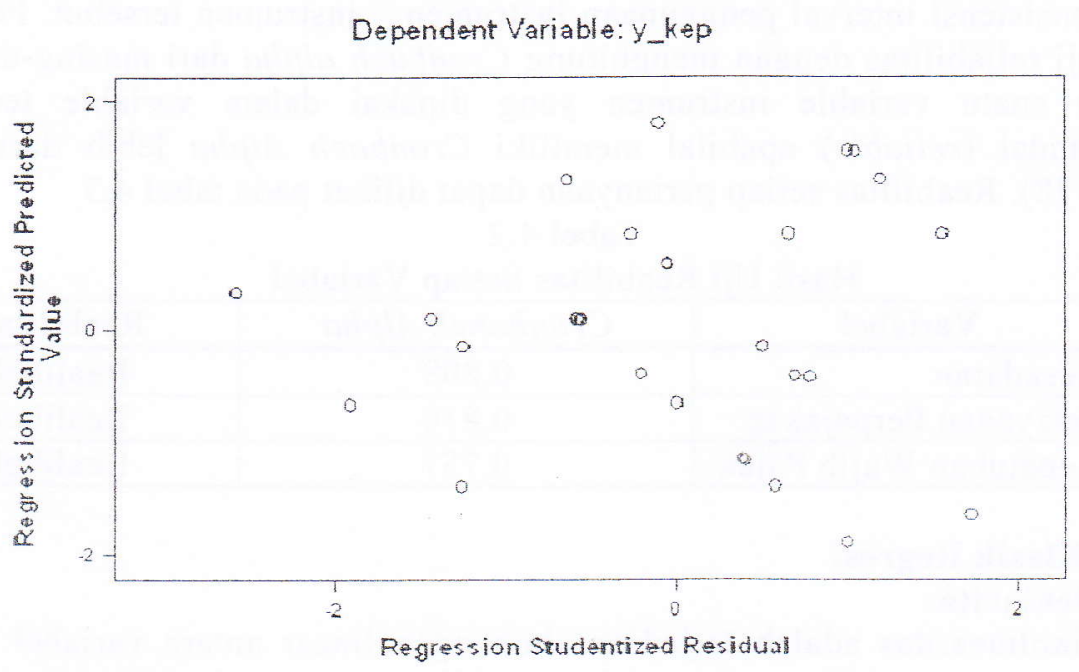

Uji Autokorelasi

Untuk mengetahui ada atau tidaknya gejala auto korelasi dalam perhitungan regresi atas penelitian ini, maka akan digunakan uji Durbin Watson. Menurut Makridarkis dkk (1995) dalam Sulaiman (2004) ketentuan pengujian Durbin Watson adalah :

a. 1,65 $<\mathrm{DW}<2,35$ maka tidak ada auto korelasi

b. $1,21<\mathrm{DW}<1,65$ atau $2,35<\mathrm{DW}<2,79$ maka tidak dapat disimpulkan

c. DW $<1,21$ atau $\mathrm{DW}>2,79$ maka terjadi auto korelasi

Tabel 4.7 : Hasil Uji Durbin Watson (DW Test)

\begin{tabular}{|c|c|c|c|c|c|c|}
\hline Model & $R$ & R Square & $\begin{array}{c}\text { Adjusted } \\
\text { R Square }\end{array}$ & $\begin{array}{c}\text { Std. Error of } \\
\text { the Estimate }\end{array}$ & $\begin{array}{c}\text { Durbin- } \\
\text { Watson }\end{array}$ & Kesimpulan \\
\hline 1 & $.611(\mathrm{a})$ & .373 & .327 & .38491 & 1.445 & Tidak terjadi \\
\hline
\end{tabular}

\section{Uji Hipotesis dan Pembahasan}

Hipotesis 1 : Terdapat pengaruh positif signifikan antara kesadaran dan pelayanan perpajakan secara parsial terhadap kepatuhan Pengusaha Kena Pajak (PKP) di Mojokerto

Berdasarkan uji t (uji secara simultan) variabel independen yaitu kesadaran dan pelayanan perpajakan memiliki pengaruh terhadap variabel dependen yaitu kepatuhan pengusaha kena pajak. Pengaruh variabel Xl (kesadaran) terhadap variabel $Y$ (kepatuhan pengusaha kena pajak) adalah positif dan signifikan. Hal tersebut dibuktikan dengan nilai t hitung sebesar 3,181, coefficient value sebesar 0,569 , standard error sebesar 0,179 dan nilai signifikasi 0,004. Dari penelitian ini dapat dikatakan bahwa semakin tinggi kesadaran pengusaha kena pajak maka semakin tinggi pula kepatuhan perpajakannya. Dari penjabaran tersebut dapat disimpulkan bahwa hasil uji t membuktikan hipotesis pertama.

Sedangkan pengaruh variabel X2 (pelayanan perpajakan) terhadap variabel $\mathrm{Y}$ (kepatuhan pengusaha kena pajak) yang diperoleh dari uji $\mathrm{t}$ di atas adalah positif dan signifikan. Hal tersebut dibuktikan dengan nilai $t$ hitung sebesar 2,131, coefficient value sebesar 0,351, standard error sebesar 0,165 dan nilai signifikasi 
0,042 yang berarti data yang dihasilkan mempunyai tingkat. Dari penelitian ini dapat dikatakan bahwa semakin tinggi (baik) pelayanan maka semakin tinggi kepatuhan pengusaha kena pajak dalam memenuhi kewajiban perpajakannya Dari penjabaran tersebut dapat disimpulkan bahwa hasil uji t membuktikan hipotesis kedua.

Hipotesis 2 : Ada pengaruh positif signifikan antara kesadaran dan pelayanan perpajakan secara simultan terhadap kepatuhan Pengusaha Kena Pajak (PKP) di Mojokerto

Hasil penelitian ini menyebutkan bahwa terdapat pengaruh secara simultan antara variabel independen terhadap variabel dependen, yaitu pengaruh positif dan signifikan. Hal ini ditunjukkan dari hasil uji f di atas dengan nilai f hitung sebesar 8,039 dan Level of Significanse sebesar 0,02. Artinya kedua variabel tersebut yaitu $\mathrm{X} 1$ (kesadaran) dan variabel $\mathrm{X} 2$ (pelayanan perpajakan) memiliki pengaruh yang sangat kuat terhadap variabel Y (kepatuhan Pengusaha Kena Pajak). Sehingga hasil positif dan signifikan, membuktikan bahwa terdapat pengaruh langsung antara kesadaran dan pelayanan perpajakan dengan kepatuhan pengusaha kena pajak sebesar 8,039 yang dibuktikan dari hasil pengujian secara simultan (uji f) di atas. Berdasarkan penjabaran tersebut, disimpulkan bahwa hasil uji f dapat membuktikan hipotesis ketiga.

\section{Simpulan}

Berdasarkan analisis dan pembahasan yang telah diuraikan pada bab IV, maka dapat diambil kesimpulan sebagai berikut:

1. Faktor kesadaran mempunyai pengaruh positif signifikan dengan nilai signifikasi sebesar 0.004 sehingga berpengaruh kuat terhadap kepatuhan wajib pajak khususnya Pengusaha Kena Pajak (PKP) yang berada di wilayah Kota Mojokerto.

2. Faktor pelayanan perpajakan mempunyai pengaruh positif signifikan dengan nilai signifikasi sebesar 0.042 sehingga berpengaruh kuat terhadap kepatuhan wajib pajak khususnya Pengusaha Kena Pajak (PKP) yang berada di wilayah Kota Mojokerto.

3. Faktor kesadaran dan pelayanan perpajakan secara simultan memiliki pengaruh positif dan signifikan yaitu dengan nilai signifikasi sebesar 0.002 terhadap kepatuhan wajib pajak khususnya Pengusaha Kena Pajak (PKP) yang berada di wilayah Kota Mojokerto

4. Berdasarkan hasil pengujian dan signifikansi diperoleh hasil bahwa ada pengaruh positif dan signifikan terhadap kepatuhan pengusaha kena pajak yang berada di wilayah Kota Mojokerto. Pada dasarnya kesadaran dan pelayanan perpajakan merupakan faktor yang sama - sama dominan dan mempunyai pengaruh positif terhadap kepatuhan wajib pajak dalam pelaporan kewajiban perpajakannya. Namun karena tingkat signifikasi variabel kesadaran lebih tinggi dari pada variabel pelayanan perpajakan, maka variabel yang dapat dikatakan lebih dominan dari keduanya adalah faktor kesadaran.

\section{Daftar Pustaka}

Blanthorne, Cynthia M., 2000. The Role of Opportunity and Beliefs On Tax Evasion $\therefore$ A Structural Equation Analysis. Dissertasion. Arizona State University. 
Bobek, D., Richard C. Hatfield,2003. An Investigation of Theory of Planned Behavior and The Role of Moral Obligation in Tax Compliance, Behavioral Research in Accounting, 15

Bradley, Cassie Francies, 1994. An Empirical Investigation of Factor Affecting Corporate Tax Compliance Behavior. Dissertation. The University of Albana, USA.

Darmayanti, Theresia Woro.2004. Pelaksanaan Self Assessment System Menurut Wajib Pajak (Studi Kasus Pada Wajib Pajak Badan Salatiga). Jurnal Ekonomi dan Bisnis, Volume X, No.1, p : $109-128$

Fallan, Lars.1999.Gender, Exposure To Tax Knowledge, and Attiudes Tiward Taxation, An Experimental Approach, Journal of Bussiness, 18 : 173-184.

Forest, Adam and Steven M. Sheffrin.2002. Complexity and Compliance: An Empirical Investigation, National Tax Journal Vol. LV, No.1, March, p.7588

Gunadi,2002. Indonesian Taxation 2002; A Reference Guide. Jakarta: Muti Utama Publishing.

Gunadi,2004. Kebijakan Pemeriksaan Pajak Pasca Berlakunya Undang - Undang Perpajakan Baru, Berita Pajak.

Hamdan. Ainie.2002. Tidak Relevannya Buku Petunjuk Pengisian dan Sering Berubahnya Format SPT, Memusingkan Wajib Pajak. Jumal Perpajakan Indonesia, $1(8), 36-40$.

Ikatan Akuntan Indonesia.2007. Modul Pelatihan Pajak Terapan Brevet A dan B.

Karanta, Maria., Hakkan Malmer, Ingrid Muck, Gunnar Olsson.2000.A Citizen's Perspective and Service Delivery, Progress in Measurement and Modelling of Dala from Swedish Tax Payer Survey. Dipresentasikan di Europan Evaluation Society EES Conference, October 12, Loussanne.

Mardiasmo.2008. Perpajakan Edisi Revisi. Yogyakarta : Andi

Muljono, Djoko.2008. Ketentuan Umum Perpajakan Lengkap dengan Undang Undang No. 28 Tahun 2007. Yogyakarta : Andi.

Prasetyo, Feri Dwi. 2006. Analisis Faktor - Faktor Yang Mempengaruhi Pemilik Usaha Kecil Menengah Dalam Pelaporan Kewajiban Perpajakan Di Daerah Jogjakarta (Studi Kasus Pada Usaha Coffeshop di Daerah Jogjakarta)

Roades, Shelley C.1999.The Impact Of Multiple Compoent Reporting In Tax Compliance Audit Strategis, The Accounting Review, Vol.74, No.1, January, p. $63-85$

Siahaan, Fadjar O.P. 2005. Faktor - Faktor Yang Mempengaruhi Perilaku Kepatuhan Tax Proffesional Dalam Pelaporan Pajak Badan Pada Perusahaan Industri Manufaktur Di Surabaya. Disertasi Program Pascasarjana Universitas Airlangga. 